\title{
Control of Mammalian Cell Behaviour Through Mimicry of the Extracellular Matrix Environment
}

\author{
Lisa McIntosh and Christopher F. van der Walle \\ Strathclyde Institute of Pharmacy and Biomedical Sciences, \\ University of Strathclyde, Glasgow, \\ United Kingdom
}

\section{Introduction}

Cell adhesion to the extracellular matrix (ECM) is primarily mediated through integrin receptors and contributes to numerous physiological and pathological processes. It would be most attractive for biomedical implants to interact with the surrounding host tissue in a manner which promotes the healing process, beginning with cell adhesion and growth. This calls for a good understanding of the mechanisms by which the ECM is involved in the control and organization of cellular processes for wound healing and tissue regeneration. Alongside the critically important fields of cell signalling, circulating hormones, cytokines and extracellular proteases, the role of the structure, organization and stiffness of the ECM can be overlooked. It is the intention of this review to discuss the various approaches that have been used to mimic the structural and dynamic aspects of native ECM proteins, and how these may modulate cell behaviour. It is clear that molecular biology has much to contribute, since protein constructs are now routinely expressed, circumventing the need to purify protein molecules (e.g. collagen, laminin, vitronectin and fibronectin) from plasma or tissue. Thus, protein engineering has become an essential tool for development of multifunctional mimics of the ECM. Since integrins mediate the signalling pathways involved in cell-ECM attachment, and subsequent self-renewal/differentiation in the case of embryonic stem cells, these cell surface receptors will be briefly introduced. The review will then move onto the key protein components of the ECM and contemporary studies which have utilised this knowledge to generate novel biomaterials able to control cell behaviour.

\section{Integrin receptors}

Integrin receptors are recognized as one of the most important cell surface adhesion and signalling receptors, and are widely expressed in many cell types such as smooth muscle, endothelium, platelets, and osteoclasts. Integrins are a family of heterodimers consisting of two transmembrane subunit proteins $(\alpha$ and $\beta$ ) that are non-covalently bound but interdependent for correct ligand binding. Eighteen $\alpha$ and eight $\beta$ subunits have been listed in humans to date with 24 dimeric combinations identified, each having distinct binding profiles to the various extracellular ligands. For instance, osteoclasts bind collagen via $\alpha_{1} \beta_{1}$ and $\alpha_{2} \beta_{1}$ integrins whereas fibroblasts bind fibronectin (FN) and vitronectin via $\alpha_{5} \beta_{1}$ and $\alpha_{v} \beta_{3}$ integrins, respectively. Several integrins can recognize the same ligands with varying 
affinity. Both a and $\beta$ subunits have large extracellular domains composed of a membrane distal, globular head ( 700-1100 residues). The crystal structures of the extracellular segment of $a_{v} \beta_{3}$ in ligand-occupied and non-occupied states have been exceptionally important in understanding the ligand/receptor recognition process at the atomic level.

Electron micrographs of the complete ectodomain, which includes the headpiece with the 'lower leg' calf and epidermal growth factor (EGF)-like domains of the $\alpha$ and $\beta$ subunits, respectively, have been acquired for integrin $\alpha_{I I b} \beta_{3}$ in its rested and activated state. It appears that the integrin receptors are in a compact 'bent' form when inactive, which results in the head domains (the $\beta$-propeller and the $\beta$-I domain of the $\alpha$ and $\beta$ subunits, respectively) lying close to the cell membrane, and an extended 'standing' conformation when activated. A low resolution electron micrograph structure of a recombinant fibronectin fragment bound to the 'headpiece' (the head domains with the thigh and hybrid/plexin-semaphorin-integrin (PSI) domains of the $\alpha$ and $\beta$ subunits, respectively) of integrin a5 $\beta 1$ has also been published. The dimensions of the integrin ectodomain in the crystal structure are approximately $80 \times 90 \times 110 \AA$ and a similar estimation can be inferred from the accompanying low resolution electron microscopy (EM) structures. Superposing the crystal structure onto the electron micrographs has also been informative to understanding the large conformational changes associated with the $\alpha / \beta$ subunits upon ligand binding and activation. Both the $\alpha$ and $\beta$ subunits span the cell membrane and interact with the actin cytoskeleton via vinculin or talin during cell signalling.

The binding of a ligand to an integrin receptor causes tyrosine phosphorylation of the $\beta$ subunit cytosolic domain by $\mathrm{v}$-src. This in turn facilitates the binding of cell actin filaments and intermediary proteins (vinculin and talin) which form complexes associated with the focal adhesion structures. Thus, integrins are thought to exist on the cell surface in an inactive form and can be activated either by binding ECM (outside-in signalling), but also by intracellular signalling (inside-out signalling). Outside-in signalling involves cell adhesion, proliferation, migration, differentiation and apoptosis. Inside-out signalling involves, for example, platelet aggregate via $\mathrm{a}_{\mathrm{II}} \beta_{3}$ activation leading to haemostasis. Integrin receptors may alternate between active and inactive states by conformational changes of the ligand binding sites from a high affinity state (active) to a low affinity state (inactive).

Integrin receptors are usually present at 10-100 fold higher concentrations on the cell surface than other non adhesive receptors. Moreover, it has been noted that integrins cluster when binding to their ligands, which can be observed at focal adhesions by immuno-microscopy. It is likely that the ECM binds a large number of integrins in a polyvalent manner, increasing binding affinity. However, tight regulation over integrin recruitment activation state and binding affinity must be maintained in order to facilitate transitional cell detachment during cell migration. In association with the formation of focal adhesions is a force dependent "adhesion strengthening" process. This adhesion reinforcement can be induced through the use of synthetic ligand matrices as discussed further below.

\section{Key protein components of the ECM}

\subsection{Vitronectin}

Vitronectin is a small multifunctional adhesive glycoprotein which is mostly present in the blood as a monomer, but can also be found as a multimer (up to 16-mer) in the ECM of various tissues. The polypeptide chains often can be in the form of two molecular species of around 60 and $75 \mathrm{kDa}$, of which up to $30 \%$ is a result of glycosylation. The recognized cell 
binding domain sequence 'arginine-glycine-aspartic acid' ('RGD') is present, facilitating binding to the integrin subtypes $\alpha_{v} \beta_{3}$ and $\alpha_{v} \beta_{5}$ and through this, cell adhesion is initiated. The formation of multimeric vitronectin clusters has been shown to increase heparin binding when compared to the monomeric form. These multimers can also form following binding of the molecule to plasminogen activity inhibitor PAI-1. More recently, it has been shown that to achieve enhancement of cell adhesion and spreading, oligomerisation must be initiated and that this process requires the heparin binding domain. A newly engineered construct called sVnHBD represents the minimal vitronectin domain requirement for integrin dependent cell adhesion and spreading function of vitronectin (Fig. 1). Senile plaques in the Alzheimer-diseased brain have been shown to have vitronectin immunoreactivity. Further study suggested that vitronectin aggregation mirrors that of amyloid protein, the misfolded products of which may therefore contribute to age-related amyloid disease.

(a)
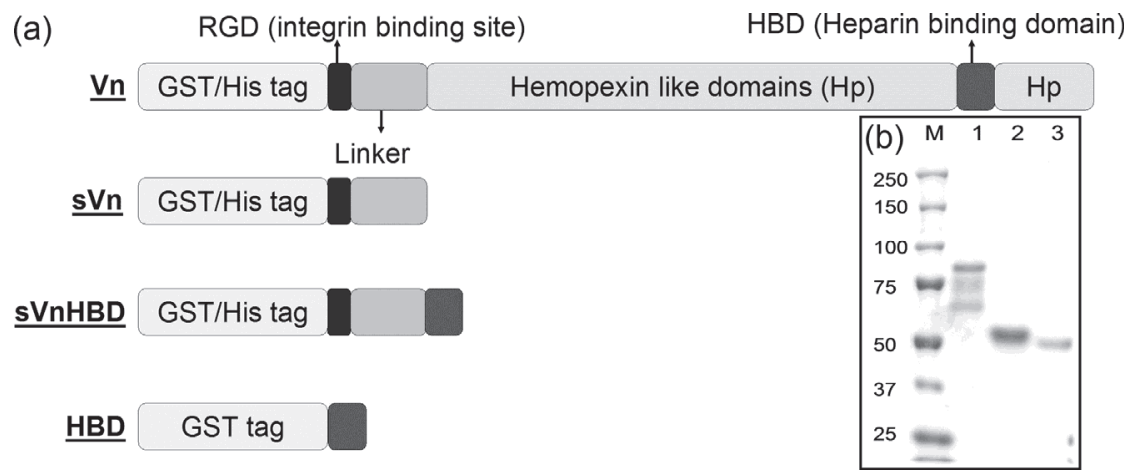

Fig. 1. (a) Recombinant vitronectin constructs: Vn, sVn, and sVnHBD constructs were generated by cloning respective vitronectin inserts into pRSETa for poly-histidine tag fusion or pGEX6P2 vector for GST fusion. (b) Purified vitronectin proteins were subjected to $12 \%$ reducing SDS-PAGE to assess the level of purity. Lane 1 is GST-Vn, lane 2 is GST-sVn and lane 3 is GST-sVnHBD. M represents the marker lane showing the marker weight in KDa. (Reprinted from FEBS Lett., vol. 584, C. R. Chillakuri, C. Jones and H. J. Mardon, Heparin binding domain in vitronectin is required for oligomerization and thus enhances integrin mediated cell adhesion and spreading, 3287-91, Copyright 2010, with permission from Elsevier.).

\subsection{Collagen}

Collagen is a multichain glycoprotein constructed from three polypeptide units forming a unique triple-helix conformation. It is a major structural component if the ECM and the most abundant of the structural proteins. There are at least 20 different kinds of genetically distinct molecules which based on structural features can be categorized as fibril forming (types I, II, III, V and XI) and network-forming (types IV, VIII and X), with type I being the most common in the ECM. This key component of the ECM is a versatile substrate for supporting cell proliferation and differentiation. Collagen in itself represents a very large, active field of research, the scope of which cannot be given justice in this review; the reader is therefore directed to previous, excellent reviews such as that by. Structural and functional collagen mimetic peptides (CMPs) harboring integrin binding motifs (GFOGER) to achieve 
'bioadhesiveness' have proven useful in the synthesis of biologically relevant matrices when used in combination with polymeric scaffolds, for the culture of hepatic cells towards liver tissue engineering. A recent innovation has been to embed collagen microfibres with defined orientations and densities in engineered elastin-like matrices, yielding thin lamellae with a specified stiffness, which have been tested in vivo in tissue engineering.

\subsection{Laminin}

Interactions via the basement membrane are mediated by the engagement of laminin with several integrins including $\alpha_{3} \beta_{1} \alpha_{6} \beta_{1} a_{7} \beta_{1} \alpha_{6} \beta_{4}$. The structural conformation of laminin involves three non-identical polypeptide chains: $\alpha, \beta$ and $\gamma$, which form cross shaped molecules in mammals. There are five $\alpha$, three $\beta$ and three $\gamma$ subunits identified which can combine to produce 15 isoforms. The function of laminin is determined by the subunit combination which can be selective for multiple cell adhesive regions including the RGD motif, which is located on the amino-terminal half of the a chain. It has been determined that integrin binding is specifically governed by the a chains. The mouse laminin a 1 chain 2719-2730 (RKRLQVQLSIRT, termed AG73) is a syndecan-binding peptide which promotes cell adhesion, migration and invasion. In an elegant study demonstrating the importance of using a composite approach to mimicry of the ECM, AG73 was combined with collagen as a cell substrate for cell culture. Human dermal fibroblasts (HDFs) developed strong actin filaments when grown on AG73/collagen substrates but not on AG73 alone or substrates with low collagen concentrations (Fig. 2). The full importance of laminin is still emerging; for example, direct interaction between laminin and retinal ganglion cells is required for full axon emergence and orientation in vivo. The design of artificial matrices incorporating laminin constructs is therefore likely to continue for the study of neural development.

\subsection{Fibronectin}

In humans, the FN gene is comprised of 46 exons within an $82 \mathrm{~kb}$ gene and is located on chromosome 2 (2q34). Due to extensive alternative splicing of FN pre-mRNA, there are 20 potential isoforms of FN leading to variants with different functions. The occurrence of splicing gives rise to insoluble cell associated $\mathrm{FN}(\mathrm{cFN})$ and soluble plasma FN (pFN). FN usually exists as a dimer of about $500 \mathrm{kDa}$ composed of two subunits linked by a disulphide bond near their C-terminus. Isopeptide bonds form between FN dimers in the N-terminal domain to form insoluble (cellular) cFN. The association of FN with cell surface integrins is the main motivator behind this process.

The FN monomers consist of three types of repeating unit, termed type I, type II and type III. Each repeating unit has a different number of amino acid residues with type I usually consisting of about 40, type II comprising of approximately 60 and type III having around 90 amino acids. Furthermore, type I and II each have two intrachain disulphide bonds while type III domains do not contain any disulphides. Typically, FN contains 12 type I repeats, each with stacked $\beta$-sheets enclosing a hydrophobic core. There are two type II repeats comprising disulphide linked perpendicular anti-parallel $\beta$-sheets. Type III repeats make up approx. $90 \%$ of the FN sequence, with 15 to 17 repeats.

There are at least 11 heterodimeric integrins which FN can bind to in a cell and tissue specific manner, the best characterised of these are integrins $\alpha_{5} \beta_{1}$ and $\alpha_{v} \beta_{3}$. FN also contains multiple binding sites for other ECM compounds including heparin and collagen. The short polypeptide sequence, RGD, located on the peptide loop in the 10th FN type III domain (FIII10) is the key attachment site for integrins. In addition to this sequence, a "synergy site" (PHSRN) has been located to the $9^{\text {th }}$ FN type III domain (FIII9), which is required for 


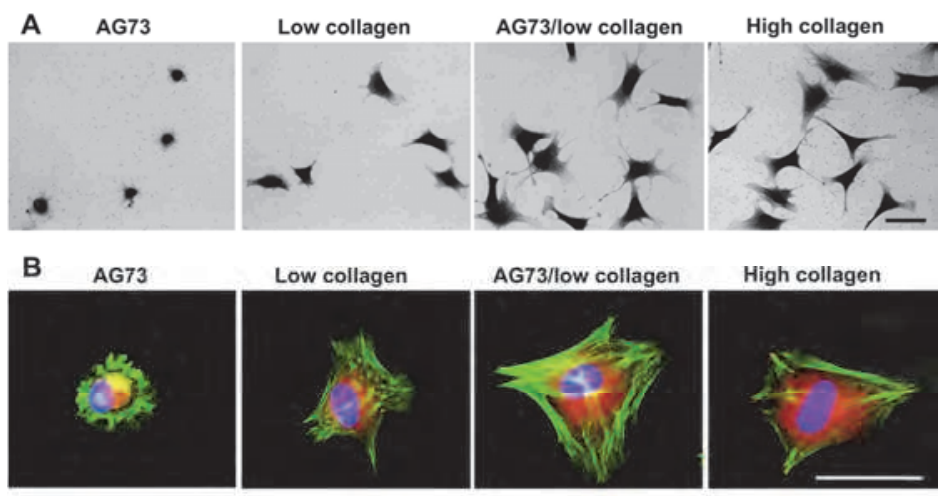

C

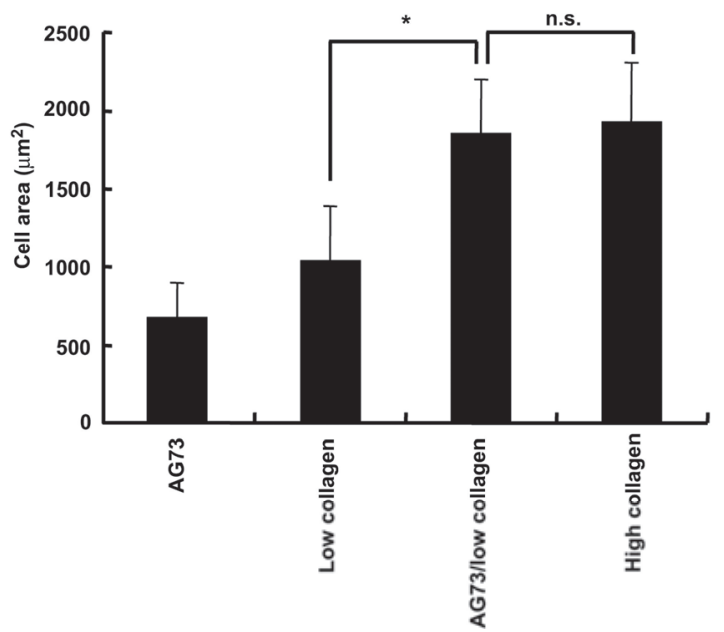

Fig. 2. Cell spreading on AG73/collagen matrices. A; HDFs $\left(5 \times 10^{3}\right.$ cells $)$ were allowed to attach for $1 \mathrm{~h}$ and then stained with crystal violet. Photomicrographs of attached cells on AG73 (3 pmol $/ \mathrm{mm}^{2}$ ), low amount of collagen matrices (Low collagen: $30 \mathrm{pg} / \mathrm{mm}^{2}$ ), AG73/low amount of collagen matrices (AG73/low collagen: AG73 $=3 \mathrm{pmol} / \mathrm{mm}^{2}$, collagen $=30 \mathrm{pg} / \mathrm{mm}^{2}$ ), and high amount of collagen matrices (High collagen: $150 \mathrm{pg} / \mathrm{mm}^{2}$ ). Scale bar $=50 \mu \mathrm{m}$. B; AG73 $\left(3 \mathrm{pmol} / \mathrm{mm}^{2}\right)$, low amount of collagen (Low collagen: 30 $\mathrm{pg} / \mathrm{mm}^{2}$ ), AG73/low amount of collagen (AG73/low collagen: AG73 $=3 \mathrm{pmol} / \mathrm{mm}^{2}$, collagen $\left.=30 \mathrm{pg} / \mathrm{mm}^{2}\right)$ were coated on 8 -well glass chambers. HDFs $\left(8 \times 10^{3}\right.$ cells $)$ were allowed to attach for $1 \mathrm{~h}$. Cells were fixed, and then stained with phalloidin, anti-vinculin antibody, and DAPI for actin filaments (green), focal contacts (red), and nucleus (blue). Scale bar $=50 \mu \mathrm{m}$. C; Images were captured and the area of the attached cells was measured using Bio Zero microscope (Keyence). The attached cells in three randomly selected fields were evaluated. Each value represents the mean \pm S.D. of triplicate experiments. Triplicate experiments gave similar results. ${ }^{*} \mathrm{P}<0.001$, n.s. $=$ not significant. (Reprinted from Biomaterials, vol 32, Y. Yamada, F. Katagiri, K. Hozumi, Y. Kikkawa, M. Nomizu, Cell behavior on protein matrices containing laminin a1 peptide AG73, 4327-35, Copyright 2011, with permission from Elsevier.) 
maximum binding to integrin $\alpha_{5} \beta_{1}$. Conformational stabilisation of FIII9 occurs through interaction with its neighbouring domains, particularly the $8^{\text {th }}$ type III FN domain (FIII8). The domain-domain mobility between FIII9 and FIII10 is unusually high; constricting this mobility by introducing an interdomain disulphide bridge brings about a change in the relative orientation between the RGD- and PHSRN-bearing loops and a decrease in $a_{5} \beta_{1}$ binding avidity (Fig. 3). Thus, while cell adhesion and spreading can be controlled through site-directed mutation of key residues in binding motifs, an alternative route would be to subtly alter the FIII9/FIII10 scaffold architecture.

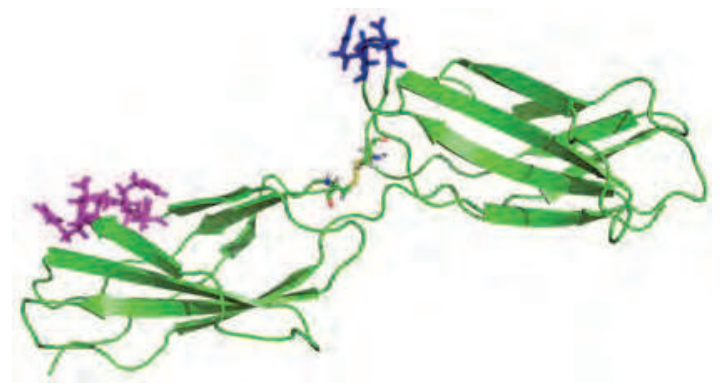

Fig. 3. Ribbon diagram of a mutant FIII9-10 domain pair constrained through an additional disulphide bridging the domain-domain interface. The PHSRN and RGD motifs on FIII9 and FIII10 are shown as sticks in magenta and blue, respectively. The added disulphide bridge is shown as sticks, with sulphurs shown in yellow. Atomic coordinates were obtained from the Protein Data Bank (www.pdb.org; ref. 1FNF) and imaged using PyMol (The PyMOL Molecular Graphics System, Version 1.2, Schrödinger, LLC).

\section{Temporal changes to the ECM}

Interaction of cells with artificial ECM matrices in vitro starts at nanoscale level (ligand/receptor) and progresses gradually to the organization of cells which can be millimetre to centimetre sized. These changes start with the binding of integrin receptor(s) to ECM protein(s), which swiftly causes integrin receptor clustering and organisation of focal adhesions. From an engineering viewpoint, it is the nanoscale which must be recapitulated in the synthetic biomaterial, ideally then permitting further temporal changes such as changes in stiffness concomitant with cell adhesion, proliferation and differentiation. This work is generally related to directed differentiation of adult stem cells, since it has been shown that the mechanical properties of hydrogels promote stem cell self-renewal. For example, maturation of cardiomyocytes is associated with a stiffening in the cells' local environment due to changes in collagen deposition. To mimic this change in a biomaterial, thiolated-hyaluronic acid (HA) hydrogels were crosslinked with poly(ethylene glycol) diacrylate of varying molecular weight, wherein the gel properties changed over time as a function of the progression of crosslinking. In this manner the stiffness of the hydrogel could be controlled to values eventually approximating cardiac tissue. Stiffening was seen to be associated with $60 \%$ more maturing muscle fibres, compared to static hydrogels.

The concept of temporal regulation of cell adhesion in synthetic scaffolds was also introduced for human mesenchymal stem cell (hMSC) culture. This built on data showing that upregulation the matrix metalloproteinase MMP-13 by hMSCs was coincident with 
down regulation of $\mathrm{FN}$ deposition, as normally required for chondrogenesis. The polyethylene glycol (PEG)-peptide matrices developed were interesting because for the first time, biomaterials with an inherent ability to down regulate cell adhesion were demonstrated. The PEG hydrogels were tethered to peptides harbouring the MMP-13 cleavage site and RGD motif (full sequence, CPENFFGRGDSG), and then utilised to encapsulate hMSCs for culture (Fig. 4). The hMSCs encapsulated in either cleavable or noncleavable (control) PEG-RGD hydrogels and cultured in chondrogenic media were seen to maintain their viability over 11 days. However, over the following 2 weeks, the hMSCs cultured in cleavable PEG-RGD substrates lost their viability by around $66 \%$ because MMP13 production caused RGD cleavage from the PEG polymeric scaffold.
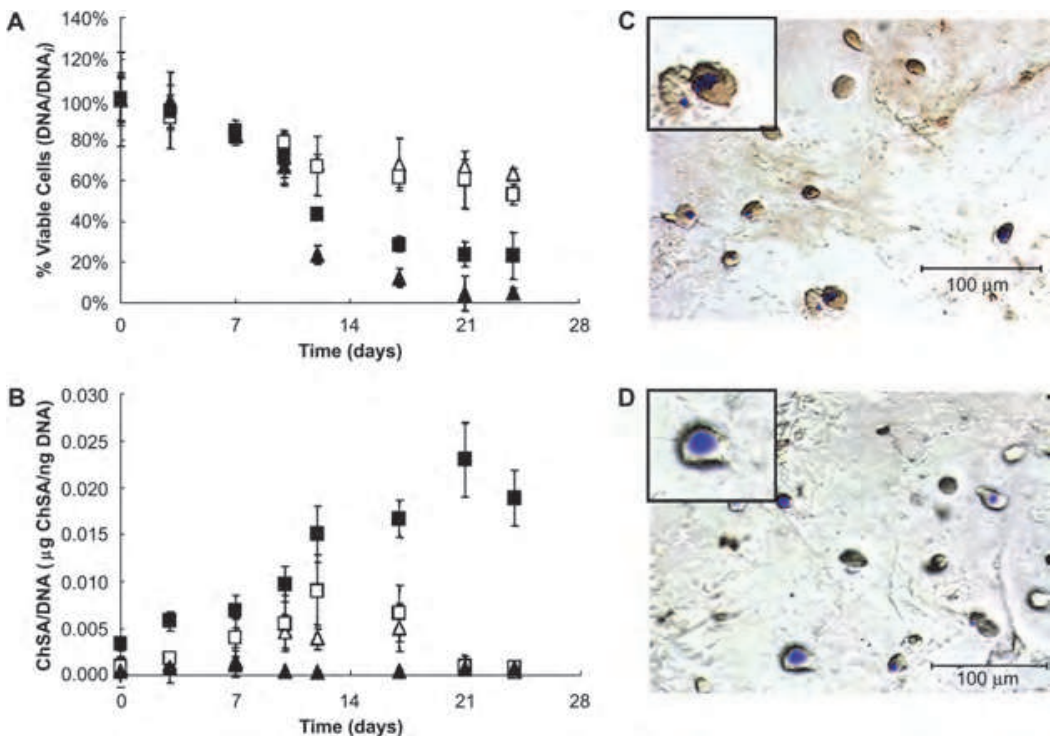

Fig. 4. hMSCs were entrapped in PEG-peptide gels in either control ( $\mathbf{\Delta})$ or chondrogenic ( $(\mathbf{\square})$ media. The composition of the gels was either PEG with 10 mM CRGDSG (non-cleavable RGD, open symbols) or PEG with 10 mM CPENFFGRGDSG (cleavable RGD tether, closed symbols). The cell constructs were analysed for viability as measured via DNA amounts and normalized to the initial time point (A). These cell/gel materials were also analysed for glycosaminoglycan deposition (B). Finally the cell-surface integrin $\left(\alpha_{5} \beta_{1}\right)$ was stained in the cleavable RGD chondrogenic culture on day 3 (C) and day 24 (D) to determine the regulation of this adhesion binding complex. Heavy red staining on day 3 is indicative of integrin surface markers, where little to no red staining on day 24 indicates that this marker has been down regulated by the cell. (Reprinted from Biomaterials, vol. 29, C. N. Salinasa and K. S. Anseth, The enhancement of chondrogenic differentiation of human mesenchymal stem cells by enzymatically regulated RGD functionalities, 2370-2377, Copyright 2008, with permission from Elsevier.)

Photo-activated cleavage is an attractive approach since it is more efficient and controllable than endogenous of exogenous enzyme mediate cleavage. Previously, photo-activated cleavage of RGD from 2-dimensional (2-D) cell substrates has also been achieved but only to 
switch cell adhesion 'on' or 'off'. The development of selectively adhesive plasticware in which the use of UV light could control the adhesion of cells was achieved by the use of photo-caged RGD based peptide. This has been done in two comparably different manners. Firstly, a carboxylic acid side chain, 3-(4,5-Dimethoxy-2nitrophenyl)-2-butyl ester (DMNPB), was introduced onto the aspartic acid of RGD. The introduction of this may have affected the steric hindrance or conformation of the peptide which reduced binding affinity, shown by reduced fibroblast cell attachment. The irradiation of the plate cleaved the DMNPB, this was demonstrated by increased DMNPB in solution measured by UV absorbance following UV incubation at $364 \mathrm{~nm}$ for 2 hours, and increased spreading of fibroblasts plated onto surface. Direct blocking of the RGD motif using a 2-nitrobenzyl group has also been employed by introduction of nitrobenzyl at the amide bond between the Gly and Arg. The placement of the group here essentially switched off the binding capability, which was then restored by UV irradiation; this was demonstrated in an exposure dependant manner. A non-linear relationship between exposure time and cell adhesion was found, suggesting that there may be an upper limit for adhesion. Although not detailed in these studies, there is the potential for cell damage from heat produced by the light source. The use of a small nitrobenzyl group would preferable in a hope that it would not irreversibly alter the binding peptide. The coupling of this with integrin selective binding peptides/proteins would be interesting for further studies to control 2-D and 3-dimentional (3-D) tissue matrices.

\section{Generating a polyvalent integrin ligand display}

\subsection{Recombinant fibronectin ligands and the 'RGD' motif}

Organization of FN fibrils in the extracellular matrix renders a polyvalent display of ligand to cell surface integrin receptors. Previous work has shown that integrin-driven polymerization of soluble FN is dependent on extension of the FN monomer in order to expose self-associating sites. The resultant fibrils are able to undergo extension/contraction over a four-fold change in length, yielding an elastic matrix. Such dynamic movements within the cell matrix inevitably change both the matrix rigidity and the spatial arrangement of the ligand display 'seen' by the cell. Interestingly, fibroblasts have been shown to probe the elasticity of their supporting matrix, responding to greater elasticity with increased motility and protruding lamellipodia but decreased 'spread' morphology. A key driver in biomaterials research has been the search for suitable mimics to the dynamic nature of the ECM, with some solutions described above. A vast amount of work has focussed on the RGD motif which is found in multiple ECM proteins and is probably the most recognized peptide sequence associated with cell adhesion. It is therefore a predictable target for simulated cell adhesion to surfaces.

However, there have been recent challenges to the extent to which peptides like RGD can accurately mimic the local cellular environment, despite ingenious engineering approaches. One concern is the ability of peptides to selectively bind the different integrin subtypes, and here protein fragments may prove more useful since they have been shown to distinguish between integrin $\alpha_{5} \beta_{1}$ and $\alpha_{5} \beta_{1}$ subtypes. Similarly, the affinity of binding to the several integrin receptors which recognize the sequence may be modulated by the conformation of the RDG loop and the surrounding amino acids within the protein. There are two fibronectin fragments which are commonly reported in the literature. The first is a domain pair encompassing the $9^{\text {th }}-10^{\text {th }}$ type III FN domains (FIII9-10), wherein a key substitution of proline for leucine-1408 in FIII9 is used to increase the conformational stability of this 
domain by introducing a Pro-Pro pair (cf. Fig. 3). This mutant, termed FIII9'10, has been used to generate polyvalent ECM mimics and support embryonic stem cells, discussed below. The second fragment is larger and encompasses the $7^{\text {th }}-10^{\text {th }}$ type III FN domains (FIII7-10). In vitro, FIII7-10 tethered surfaces promoted rat bone marrow stromal cells adhesion via integrin $\alpha_{5} \beta_{1}$ while in vivo, FIII7-10 functionalized implants placed in artificially created rat tibia cortical defects, exhibited a $70 \%$ increase in the bone-implant contact area. A third, recent chimeric fibronectin fragment has been reported which brings the heparin-binding $1^{\text {st }}$ type III FN domain alongside the $8^{\text {th }}$ type III FN domain, which was further engineered to harbour the RGD motif (termed III1H, $8^{\mathrm{RGD}}$ ). A series of related, larger chimeras incorporating $8^{\text {th }}, 9^{\text {th }}$ and $10^{\text {th }}$ type III domains were also described. The advantage in utilising the heparin binding domain was shown to lie in generating higher rates of cell proliferation.

\subsection{Monomeric versus multimeric ligands}

Since FN exists in the ECM as a dimer presenting six cell adhesion domains within a small area, when emulating this polyvalent display it would be prudent to strive for a similar tactic, suggesting that multimeric, clustered ligands would be preferable. Multimeric ligands displaying the RGD motif have been shown to better support cell motility and migration compared to monomeric ligands. Furthermore, higher ligand density and cluster size has been shown to increased the strength of attachment of fibroblast cells. Although simple nonclustered RGD ligands were capable of supporting cell attachment, they were unable to exhibit full spreading of fibroblast cells. An alternative approach to generating a polyvalent RGD display as has been the self-assembly of $\beta$-sheet peptides harboring RGD which form regular nanofibre structures. Some related amphiphilic peptide assemblies have involved elaborate work to include both the RGD and PHSRN peptide motifs, generating fibres around $10 \mathrm{~nm}$ in diameter and several microns in length. Such self-assembly approaches challenge the need to coat non-functional polymeric 3-D scaffolds with bioadhesive peptides/proteins, but may be limited with regard to scale-up/cost for clinical application. However, as mentioned above, RGD peptides have certain limitations in their ability to recapitulate key aspects of the ECM, particularly integrin subtype selection. The challenge is to design self-assembling systems for protein fragments, but taking into account their labile nature: that is, one cannot simply expose proteins to synthetic chemistry which involves organic solvents likely to unfold the protein fragment. Ideally, the self assembly of proteins would involve the independent formation of an organized stable structure through noncovalent forces such as hydrogen bonds, ionic bonds and van der Waals interactions. The application of self assembling proteins is diverse and has included the $\mathrm{pH}$ induced formation of a self assembled artificial protein hydrogels. Application to biomimetic materials has been explored by compiling helical coiled-coils for di-, tri- and tetra-helical multimers. The stability and order of these coiled coil structures has been encouraging for application towards functional biomaterials.

The construction of a coiled coil system involving FN has been achieved by selective mutation of key amino acids in a heptad repeat of the GCN4 leucine zipper helix to allow for direct self assembly of parallel coiled coils. A spacer based on an IgG hinge was included to prevent steric clashes between bound integrin receptors (i.e. N-FIII9'10-hinge-coiled coilC). In this case, the mutant fibronectin fragment FIII9'10 was utilized because of its previously reported conformational stability. In this way, the FIII9'10-dimer, -trimer and tetramer were constructed, and the effect of these multimeric systems on baby hamster 
kidney cells and primary endometrial stromal cells was analysed. For both fibroblast and stromal cell lines, increased cell attachment and spreading were observed with increasing multimerisation of FIII9'10. The morphology of the spread stromal cells on the FIII9'10tetramer recapitulated their spread morphology on FN (Fig. 5), and suggests that multimeric constructs will have a role to play in endometrial tissue engineering. Translation of these cell data from 2-D ligand displays to 3-D scaffolds under perfusion culture is currently underway.

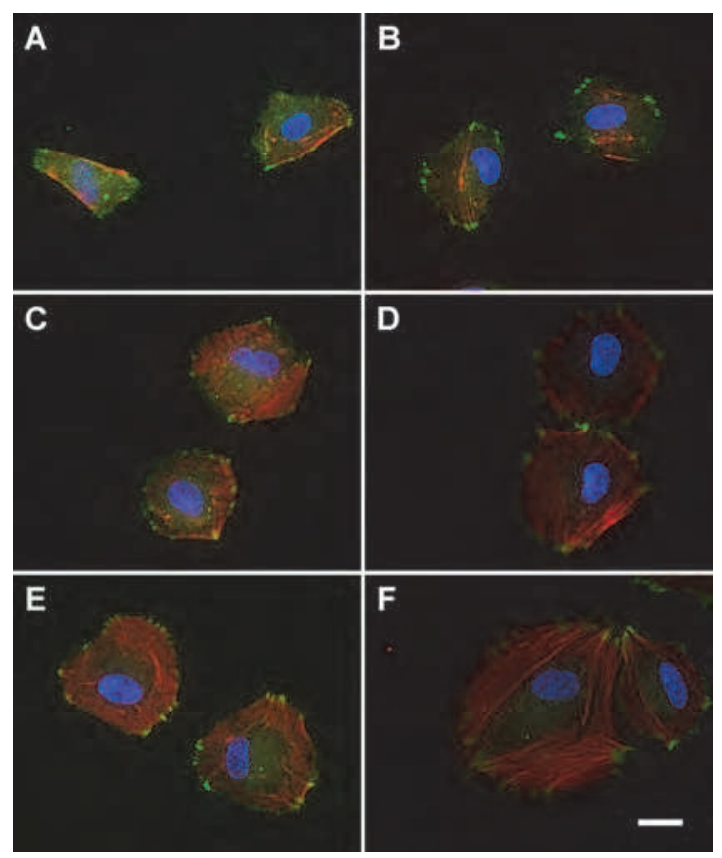

Fig. 5. Morphology of EnSCs on surfaces derivatised with multimeric and monomeric integrin a5 $\beta 1$ ligands. Cells were plated onto neutravidin surfaces incubated with $0.5 \mu \mathrm{M}$ ligand coating concentration of FIII9'10-GGC (A), FIII9'10 (B), dimer (C), trimer (D), tetramer (E) and FN (F), and stained for vinculin (green), actin (red), and nuclei (blue). Bar, $16 \mu \mathrm{m}$. (Reprinted from Biochem. Biophys. Res. Commun., vol. 407, Z. Li, M. Kreiner, C. F. van der Walle, H. J. Mardon, Clustered integrin a $5 \beta 1$ ligand displays model fibronectin-mediated adhesion of human endometrial stromal cells, 777-82, Copyright 2008, with permission from Elsevier.).

\section{Non specific versus directed protein adsorption}

Non-specific adsorption of a protein to a surface usually involves the incubation of the desired surface in a protein solution. The protein adsorbs to the surface through non specific interactions such as hydrophobic and electrostatic forces. Directed protein adsorption through covalent surface modification involves the attachment of mechanisms to the ligand display. These can be in the form of, polymer side chains, self assembling monolayers or components of a lipid bilayer. The generation of model substrates which present defined 
binding motifs, such as RGD, from the ECM are subjected to many issues. The importance of ligand conformation may be compromised by the immobilized proteins undergoing denaturation or adsorption in the 'incorrect' orientation (i.e. resulting in the ligand not being available for receptor binding). In order to have well defined substrates with reproducible results these changes during adsorption should be characterized and/or controlled.

The non-specific adsorption of a protein from bulk solution to a solid/liquid interface may incur: i) a change in its conformation, ii) relaxation and partial desorption, iii) reorientation and alignment as a function of surface coverage. The protein layer may also undergo transition from a monolayer to a multilayer as the surface becomes saturated. Changes in orientation and surface coverage were seen for random adsorption of FN fragments, wherein the adsorption model was analogous to the surface pressure area isotherm of surfactants. Concomitant structural changes were also observed during the random adsorption of FIII' 10 to silica, wherein a distorted, non-native conformation was observed to be associated with the aromatic residues being held in a more ridged state. However, in order to better define the relationship between cell behavior and a 2-D ligand display, it is necessary to characterise the ligand pattern and density that is interrogated by the cell surface integrin receptors. This requires an engineering approach in which ligands are tethered in a controlled manner to the surface. Such approaches have been described for RGD-peptides at least, with the development of comb-like polymers and self-assembling monolayers (SAMs) permitting the calculation of ligand densities and ligand clustering.

Application of SAMs to larger protein domains remains unclear since the cross-linking of proteins to the gold/alkanethiolate brush border appears to leave significant proportions of the immobilised protein non-specifically adsorbed. Similarly, one report for cross-linking FIII7-10 to adsorbed BSA did not address random ligand orientation or adsorption-induced unfolding. A carrier or tether facilitating uniform ligand orientation upon immobilisation is therefore required. Such tethers have been described for FN fragments, using either a unique C-terminal cysteine residue which can be specifically biotinlylated for controlled binding to a streptavidin surface (Fig. 6), or covalent conjugation through a synthetic protocol. With respect to the latter, clinical-grade titanium implants grafted with a nonfouling polymer coating, functionalised with a controlled density $\left(0.9 \mathrm{pmol} / \mathrm{cm}^{2}\right)$ of FIII7-10 have been tested in vitro and in vivo (Fig. 7). It is also possible to translate the specific ligand orientation that can be achieved in 2-D through the use of tether to 3-D scaffolds, so long as the appropriate chemistry is based on aqueous solvents which maintain protein integrity.

\section{Stem cell behavior and substrate 'stiffness'}

An important outcome of the studies on ECM-directed control of cell behaviour will be improvements in our ability to grow mammalian embryonic stem (ES) cells in culture systems completely free of animal material. Given the therapeutic potential for cultured cells, development of such animal free systems is a major imperative. This is most pressing in the field of stem cell biology where human ES (hES) cells provide a potentially novel source for the derivation of transplantable tissue specific cell types. ES cells were initially developed from the inner cell mass of the $\mathrm{d} 3.5$ murine blastocyst and have been demonstrated to be capable of contributing to all three germ layers of the developing embryo. These murine ES (mES) cells can differentiate in vitro to give rise to a wide range of 


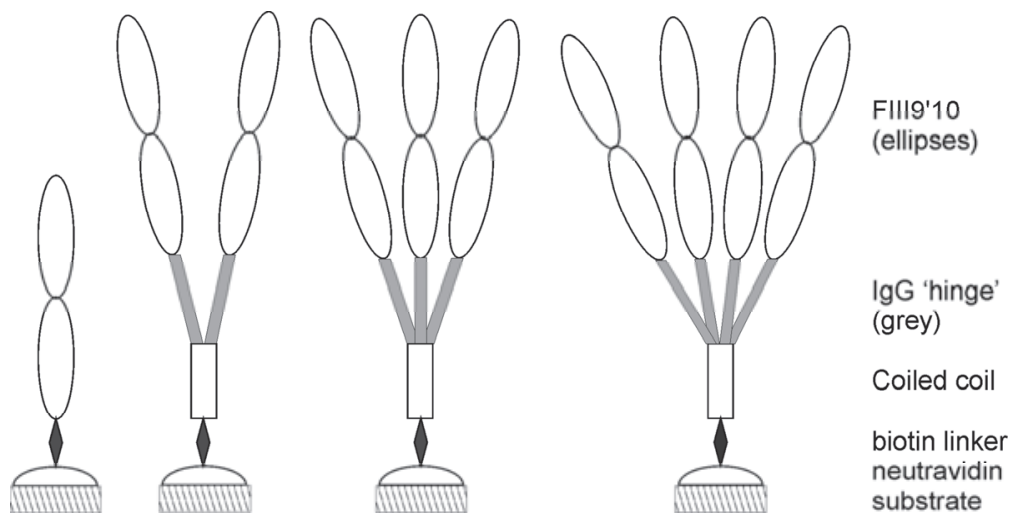

Fig. 6. Cartoons of the biotinylated monomeric (FIII9'10-GGC) and multimeric integrin $a_{5} \beta_{1}$ ligands orientated to the neutravidin coated 2D substrates. (Reprinted from Biochem. Biophys. Res. Commun., vol. 407, Z. Li, M. Kreiner, C. F. van der Walle, H. J. Mardon, Clustered integrin a5 $\beta 1$ ligand displays model fibronectin-mediated adhesion of human endometrial stromal cells, 777-82, Copyright 2008, with permission from Elsevier.).

A

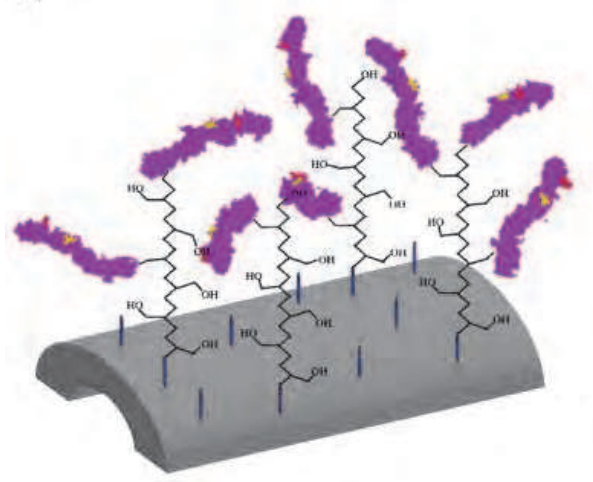

B

(1)

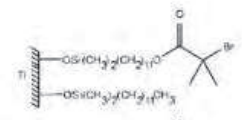

(2)

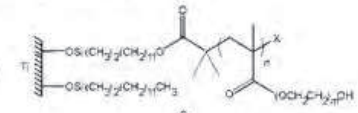

(3)

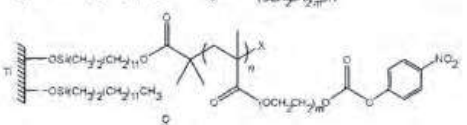

(4)

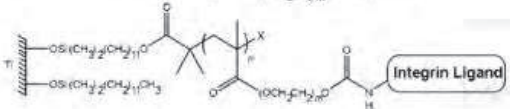

Fig. 7. Poly(OEGMA) brushes with ligand tethered on titanium. (A) Schematic of FNIII7-10tethered poly(OEGMA) brush system on titanium. Both linear RGD peptide and a fibronectin fragment FNIII7-10 (purple) containing both the RGD (red) and PHSRN (yellow) sequence in the native ECM structural conformation were tethered to poly(OEGMA) brushes via NPC chemistry. Unactivated hydroxyl groups provided the non-fouling nature of the brushes. (B) Tethering scheme of integrin ligands to "activated" poly(OEGMA) brushes on titanium. (Reprinted from Biomaterials, vol. 29, T. A. Petrie, J. E. Raynor, C. D. Reyes, K. L. Burns, D. M. Collard, A. J. García, The effect of integrin-specific bioactive coatings on tissue healing and implant osseointegration, 2849-57, Copyright 2008, with permission from Elsevier.).

mature cell types such as haemopoietic cells, cardiac muscle cells, endothelial cells and neurons. Isolated hES cells have also been shown to contribute to all three germ layers. The ability of these cells to differentiate in vitro to give rise to a range of tissue cell types has 
prompted much research into the use of these hES cells as sources of transplantable cells. Whilst this currently looks like a promising option, clinical use of these cells will require extremely well defined culture systems and thus any advances in our understanding of the use of synthetic replacements for animal products in the regulation of self-renewal and differentiation of ES cells will be important.

The nature of the ECM is also known to regulate ES cell behavior. For example, mES cells cultured on type I and type IV collagen or poly-D-lysine retained an undifferentiated state but when cultured on laminin or FN displayed altered morphology and downregulated signal transducer and activator of transcription 3, which maintains ES cell self-renewal. Inhibition of integrin-fibronectin binding prevented the observed differentiation response and in serum-replacement media the mES cells expressed integrin subtypes specific for laminin and fibronectin, but not for collagen. It is therefore apparent that the integrin subtype specific for fibronectin, namely integrin $\alpha_{5} \beta_{1}$, is likely to play a role in mES cell behavior upon adhesion to ECM. As for stromal and fibroblast cells (discussed above), mES cells showed clear morphological responses to clustered versus monomeric FN fragments. The mES colonies appeared disperse with a spread cell morphology on dimeric FIII9'10, unless subdued back to a tight morphology with increasing concentrations of leukaemia inhibitory factor (LIF) (Fig. 8). In the presence of LIF, mES cells adherent to the FIII9'10dimer also showed transient upregulation of Oct-4, the mesodermal transcription factor, Brachyury, and the ectodermal marker, Nestin. However, dual upregulation of Nanog maintained the mES cells in a pluripotent state, confirmed by alkaline phosphatase staining. Since the mES cells grow as dispersed colonies in a monolayer, FIII9'10-dimer could have application as an alternative substrate on which to study ES cell differentiation in 2-D.

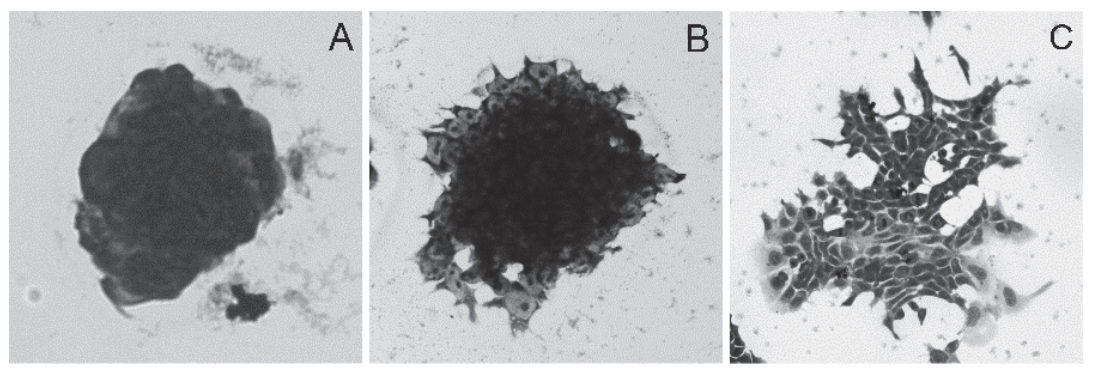

Fig. 8. mES cells stained with Giemsa after culture in complete media for 3 days and adherent to $0.1 \%$ gelatin (A), or $100 \mu \mathrm{g} / \mathrm{ml}$ FIII9'10-dimer on which there appear 'tight' (B) and 'dispersed' (C) mES cell colonies; magnification $\times 20$. (Reprinted from Biochem. Biophys. Res. Commun., vol. 390, M. D. Singh, M. Kreiner, C. S. McKimmie, S. Holt, C. F. van der Walle, G. J. Graham, Dimeric integrin $\alpha_{5} \beta_{1}$ ligands confer morphological and differentiation responses to murine embryonic stem cells, 716-721, Copyright 2009, with permission from Elsevier.)

However, cellular responses to ECM signals are context-dependent: ECM signals presented in 3-D differ from those presented in 2-D. For example, focal adhesion formation during cellECM adhesion is mechanistically different in naturally derived hydrogels when compared to protein-coated tissue culture polystyrene substrates. These context dependent changes are due to cell-substrate mechanics, involving local forces generated by the cell during spreading and primary (tissue) cell sensing of the synthetic substrate stiffness, or local 
variations of ECM elasticity in vivo. Termed 'mechanotransduction', this field of study is of clear relevance to the design and interpretation of tissue culture on 3D matrices. Mechanical cues can also direct adult stem cell commitment. Human mesenchymal stem cells can be induced to differentiate into multiple tissue lineages by simple altering substrate compliance: softer substrates (0.1-1 kPa) induce neurogenic differentiation, stiffer substrates $(8-17 \mathrm{kPa})$ promote muscle formation, while the stiffest substrates $(25-40 \mathrm{kPa})$ produce bone cells. In contrast, undifferentiated D1 stem cells (a mouse clonally derived bone marrow stromal cell line) show little sensitivity to hydrogel elasticity $(20-110 \mathrm{kPa})$, whereas once they are differentiated towards the osteoblast lineage, they became more responsive. Mechanical control of phenotype is thus likely to be important for different adult stem cells at various stages of differentiation.

This will involve developing hydrogels containing a bioinert polymer that is furnished with spatially defined ECM-derived ligands, while avoiding non-specific interactions with other molecules. A defined synthetic biomaterial is preferred over 'naturally based' hydrogels such as Matrigel and collagens which are biochemically complex (to tune), variable and illdefined, and therefore make interpretation of cellular responses more complex. Hydrogels are particularly promising because they do not only have a high water content to promote cell viability, but they are structurally and mechanically similar to the native ECM of many tissues. The polymers forming the hydrogel structure must be bioinert, rather than having inherent cell adhesive activity such as gels of fibrin or hyaluronan, in order to test the capacity of the gels to support a specific cell function. Bioinert polymers such as alginate or poly(ethylene glycol) must therefore be covalently cross-linked with ECM-derived ligands to physically resist cell traction forces and prevent ligand leaching.

The role of integrins in determining self-renewal versus differentiation has been investigated using mES cells embedded in hydrogels functionalised with three peptides selective for integrins $\alpha_{5} \beta_{1}, a_{v} \beta_{5}, \alpha_{6} \beta_{1}$ and $\alpha_{9} \beta_{1}$. Broadly, maintenance of mES cell selfrenewal and pluripotency, with down-regulation of differentiation-related genes, required multiple integrin subtype binding. It has also been shown that hES cells adherent to Matrigel predominantly expressed integrin $\alpha_{6}, a_{v} \beta_{3}, a_{2} \beta_{1}$ and (particularly) $\beta_{1}$. These synthetic gels were functionalised with three peptides engaging integrins $\alpha_{v} \beta_{3}, \alpha_{5} \beta_{1}$ and $\alpha_{6} \beta_{1}$. As for mES cells, maintenance of self-renewal required multiple integrin engagement, with hydrogels functionalised with one peptide supporting only hES cell adhesion and pluripotency. Integrin-mediated adhesion has also been shown to regulate the assembly of single-cell suspensions of hES cells into pluripotent hES cell colonies in the absence of feeder cells or added cytokines.

A degree of control over cellular processes is desired for regenerative medicine and to this end, FN fragments (FIII9'10) designed to specifically target integrin $\alpha_{5} \beta_{1}$ were investigated in the context of osteogenic differentiation. When FIII9'10 was coated onto surfaces, human mesenchymal stem cells displayed increased adhesion, proliferation and spreading compared to the (conformationally less stable) wild type FIII9-10. Interestingly, selective inhibition of $\alpha_{5} \beta_{1}$ was shown to reduce proliferation of cells on FIII9'10 and FIII9-10 but not on FN or FIII10, suggesting a degree of specificity. Furthermore, stronger osteoinduction potential was exhibited by the FN fragments containing FIII9 compared with full length FN and domain FIII10. The lower osteoinductive effects shown on FIII10 would be expected because it does not include the PHSRN synergy site which is required for full $a_{5} \beta_{1}$ integrin binding. FIII9'10 appears to better mimic full length FN with the addition of improved 
osteoinductive effects mediated through the $\alpha_{5} \beta_{1}$ integrin, and this may prove useful for the further development controlled cell systems.

\section{Conclusion}

It is highly desirable to control ES cell proliferation and differentiation on 2-D and 3-D substrates in order to generate clinically useful tissues for regenerative medicine. To achieve this it will be necessary to recapitulate the ES cell niche in vivo, taking into account dynamic changes to this environment. Bone formation for example is a complex process which encompasses the recruitment and proliferation of osteoprogenitor cells, differentiation, matrix formation and mineralization. It is clear then that the field of ECM engineering for the control of cell behaviour must align with complementary fields, namely soluble cytokines and growth hormones that are required constituents of cell media and also direct cell behaviour. However, it should not be overlooked that scale-up of cell culture for medical applications presents another challenge, wherein cell substrates must be conducive to fermentor/cell expansion technologies. While the biomaterials field has focussed on assembling peptide motifs which mimic the central cell binding domains of ECM proteins, particularly RGD, there appears to be a current move towards the use of protein fragments which can incorporate multi-functional roles. It is unlikely that any one ECM mimic will gain predominance, not only because each cell type expresses specific integrin subtypes, but also because of the various potential uses, from regenerative medicine to bioprocessing.

\section{References}

Adams, J. C. E. (2002). Methods in Cell-matrix Adhesion, Academic Press, ISBN 13: 978-0-12544168-1, San Diego, USA

Alberts, B.; Bray, D; Lewis, J.; Raff, M.; Roberts, K.; Watson, J. D. (1994). Molecular Biology of the Cell 3rd edition, Garland Publishing, Inc., ISBN-10: 0-8153-1619-4, New York, USA

Altroff, H.; Schlinkert, R.; Van Der Walle, C. F.; Bernini, A.; Campbell, I. D.; Werner, J. M. \& Mardon, H. J. (2004). Interdomain Tilt Angle Determines Integrin-Dependent Function of the Ninth and Tenth FIII Domains of Human Fibronectin. J. Biol. Chem., Vol.279, No.53, pp. 55995-56003

Altroff, H.; Van Der Walle, C. F.; Asselin, J.; Fairless, R.; Campbell, I. D. \& Mardon, H. J. (2001). The Eighth FIII Domain of Human Fibronectin Promotes Integrin Alpha5Beta1 Binding Via Stabilization of the Ninth FIII Domain. J. Biol. Chem., Vol.276, No.42, pp. 38885-92

Aota, S.; Nomizu, M. \& Yamada, K. M. (1994). The Short Amino-Acid-Sequence Pro-His-SerArg-Asn in Human Fibronectin Enhances Cell-Adhesive Function. J. Biol. Chem., Vol.269, No.40, pp. 24756-24761

Balaban, N. Q.; Schwarz, U. S.; Riveline, D.; Goichberg, P.; Tzur, G.; Sabanay, I.; Mahalu, D.; Safran, S.; Bershadsky, A.; Addadi, L. \& Geiger, B. (2001). Force and Focal Adhesion Assembly: A Close Relationship Studied Using Elastic Micropatterned Substrates. Nat. Cell Biol., Vol.3, No.5, pp. 466-72

Balian, G.; Click, E. M. \& Bornstein, P. (1980). Location of a Collagen-Binding Domain in Fibronectin. J. Biol. Chem., Vol.255, No.8, pp. 3234-3236 
Barker, T. H. (2011). The Role of Ecm Proteins and Protein Fragments in Guiding Cell Behavior in Regenerative Medicine. Biomaterials, Vol.32, No.18, pp. 4211-4

Beckerle, M. C. (Ed.). (2001). Cell Adhesion, Oxford University Press, ISBN 019963871 3, Oxford, UK

Berman, H. M.; Battistuz, T.; Bhat, T. N.; Bluhm, W. F.; Bourne, P. E.; Burkhardt, K.; Feng, Z.; Gilliland, G. L.; Iype, L.; Jain, S.; Fagan, P.; Marvin, J.; Padilla, D.; Ravichandran, V.; Schneider, B.; Thanki, N.; Weissig, H.; Westbrook, J. D. \& Zardecki, C. (2002). The Protein Data Bank. Acta Crystallogr. D Biol. Crystallogr., Vol.58, Pt.6 No.1, pp. 899907

Calderwood, D. A.; Shattil, S. J. \& Ginsberg, M. H. (2000). Integrins and Actin Filaments: Reciprocal Regulation of Cell Adhesion and Signaling. J. Biol. Chem., Vol.275, No.30, pp. 22607-10

Caves, J. M.; Cui, W.; Wen, J.; Kumar, V. A.; Haller, C. A. \& Chaikof, E. L. (2011). ElastinLike Protein Matrix Reinforced with Collagen Microfibers for Soft Tissue Repair. Biomaterials, (May 5), in press

Chillakuri, C. R.; Jones, C. \& Mardon, H. J. (2010). Heparin Binding Domain in Vitronectin Is Required for Oligomerization and Thus Enhances Integrin Mediated Cell Adhesion and Spreading. FEBS Lett., Vol.584, No.15, pp. 3287-3291

Cukierman, E.; Pankov, R.; Stevens, D. R. \& Yamada, K. M. (2001). Taking Cell-Matrix Adhesions to the Third Dimension. Science, Vol.294, No.5547, pp. 1708-1712

Cushing, M. C. \& Anseth, K. S. (2007). Materials Science. Hydrogel Cell Cultures. Science, Vol.316, No.5828, pp. 1133-4

Cutler, S. M. \& Garcia, A. J. (2003). Engineering Cell Adhesive Surfaces That Direct Integrin Alpha5beta1 Binding Using a Recombinant Fragment of Fibronectin. Biomaterials, Vol.24, No.10, pp. 1759-70

Dillow, A. K., Lowman, A.M. (Eds.). (2002). Biomimetic Materials and Design : Biointerfacial Strategies, Tissue Engineering, and Targeted Drug Delivery, Marcel Dekker, ISBN 0 82470791 5, New York, USA

Discher, D. E.; Janmey, P. \& Wang, Y. L. (2005). Tissue Cells Feel and Respond to the Stiffness of Their Substrate. Science, Vol.310, No.5751, pp. 1139-43

Drury, J. L. \& Mooney, D. J. (2003). Hydrogels for Tissue Engineering: Scaffold Design Variables and Applications. Biomaterials, Vol.24, No.24, pp. 4337-51

Engler, A. J.; Sen, S.; Sweeney, H. L. \& Discher, D. E. (2006). Matrix Elasticity Directs Stem Cell Lineage Specification. Cell, Vol.126, No.4, pp. 677-89

Evseenko, D.; Schenke-Layland, K.; Dravid, G.; Zhu, Y. H.; Hao, Q. L.; Scholes, J.; Wang, X. C.; Maclellan, W. R. \& Crooks, G. M. (2009). Identification of the Critical Extracellular Matrix Proteins That Promote Human Embryonic Stem Cell Assembly. Stem Cells Dev., Vol.18, No.6, pp. 919-927

Faull, R. J. \& Ginsberg, M. H. (1996). Inside-out Signaling through Integrins. J. Am. Soc. Nephrol., Vol.7, No.8, pp. 1091-7

Friess, W. (1998). Collagen - Biomaterial for Drug Delivery. Eur. J. Pharm. Biopharm., Vol.45, No.2, pp. 113-136

Green, J. A. \& Yamada, K. M. (2007). Three-Dimensional Microenvironments Modulate Fibroblast Signaling Responses. Adv. Drug Deliv. Rev., Vol.59, No.13, pp. 1293-8 
Harley, B. a. C. \& Gibson, L. J. (2008). In Vivo and in Vitro Applications of Collagen-Gag Scaffolds. Chem. Eng. J., Vol.137, No.1, pp. 102-121

Hayashi, M.; Schlesinger, D. H.; Kennedy, D. W. \& Yamada, K. M. (1980). Isolation and Characterization of a Heparin-Binding Domain of Cellular Fibronectin. J. Biol. Chem., Vol.255, No.21, pp. 17-20

Hayashi, Y.; Furue, M. K.; Okamoto, T.; Ohnuma, K.; Myoishi, Y.; Fukuhara, Y.; Abe, T.; Sato, J. D.; Hata, R. \& Asashima, M. (2007). Integrins Regulate Mouse Embryonic Stem Cell Self-Renewal. Stem Cells, Vol.25, No.12, pp. 3005-15

Hersel, U.; Dahmen, C. \& Kessler, H. (2003). Rgd Modified Polymers: Biomaterials for Stimulated Cell Adhesion and Beyond. Biomaterials, Vol.24, No.24, pp. 4385-4415

Hsiong, S. X.; Cooke, P. H.; Kong, H. J.; Fishman, M. L.; Ericsson, M. \& Mooney, D. J. (2008). Afm Imaging of Rgd Presenting Synthetic Extracellular Matrix Using Gold Nanoparticles. Macromol. Biosci., Vol.8, No.6, pp. 469-77

Humphries, M. J. (2000). Integrin Structure. Biochem. Soc. Trans., Vol.28, No.4, pp. 311-39

Hynes, R. O. (2002). Integrins: Bidirectional, Allosteric Signaling Machines. Cell, Vol.110, No.6, pp. 673-87

Ilic, D. (2006). Culture of Human Embryonic Stem Cells and the Extracellular Matrix Microenvironment. Regen. Med., Vol.1, No.1, pp. 95-101

Irvine, D. J.; Ruzette, A. V.; Mayes, A. M. \& Griffith, L. G. (2001). Nanoscale Clustering of Rgd Peptides at Surfaces Using Comb Polymers. 2. Surface Segregation of Comb Polymers in Polylactide. Biomacromolecules, Vol.2, No.2, pp. 545-56

Khew, S. T.; Zhu, X. H. \& Tong, Y. W. (2007). An Integrin-Specific Collagen-Mimetic Peptide Approach for Optimizing Hep3b Liver Cell Adhesion, Proliferation, and Cellular Functions. Tissue Eng., Vol.13, No.10, pp. 2451-63

Koo, L. Y.; Irvine, D. J.; Mayes, A. M.; Lauffenburger, D. A. \& Griffith, L. G. (2002). CoRegulation of Cell Adhesion by Nanoscale Rgd Organization and Mechanical Stimulus. J. Cell Sci., Vol.115, No.7, pp. 1423-1433

Kreiner, M.; Chillakuri, C. R.; Pereira, P.; Fairhead, M.; Li, Z.; Mardon, H. J.; Holt, S. A. \& Van Der Walle, C. F. (2009). Orientation and Surface Coverage of Adsorbed Fibronectin Cell Binding Domains and Bound Integrin A5 $\beta 1$ Receptors. Soft Matter, Vol.5, No.20, pp. 3954-62

Kreiner, M.; Li, Z.; Beattie, J.; Kelly, S. M.; Mardon, H. J. \& Van Der Walle, C. F. (2008). SelfAssembling Multimeric Integrin Alpha 5 Beta 1 Ligands for Cell Attachment and Spreading. Prot. Eng. Des. Sel., Vol.21, No.9, pp. 553-560

Laukaitis, C. M.; Webb, D. J.; Donais, K. \& Horwitz, A. F. (2001). Differential Dynamics of Alpha 5 Integrin, Paxillin, and Alpha-Actinin During Formation and Disassembly of Adhesions in Migrating Cells. J. Cell Biol., Vol.153, No.7, pp. 1427-40

Lee, S. T.; Yun, J. I.; Jo, Y. S.; Mochizuki, M.; Van Der Vlies, A. J.; Kontos, S.; Ihm, J. E.; Lim, J. M. \& Hubbell, J. A. (2009). Engineering Integrin Signaling for Promoting Embryonic Stem Cell Self-Renewal in a Precisely Defined Niche. Biomaterials, Vol.31, No.6, pp. 1219-26

Li, Z.; Kreiner, M.; Edrada-Ebel, R.; Cui, Z.; Van Der Walle, C. F. \& Mardon, H. J. (2011a). Perfusion Culture Enhanced Human Endometrial Stromal Cell Growth in Alginate- 
Multivalent Integrin Alpha5 beta1 Ligand Scaffolds. J. Biomed. Mater. Res. A, in press DOI: 10.1002/jbm.a.33177

Li, Z.; Kreiner, M.; Van Der Walle, C. F. \& Mardon, H. J. (2011b). Clustered Integrin Alpha5beta1 Ligand Displays Model Fibronectin-Mediated Adhesion of Human Endometrial Stromal Cells. Biochem. Biophys. Res. Commun., Vol.407, No.4, pp. 77782

Ling, Y.; Maile, L. A. \& Clemmons, D. R. (2003). Tyrosine Phosphorylation of the Beta3Subunit of the Alphavbeta3 Integrin Is Required for Embrane Association of the Tyrosine Phosphatase Shp-2 and Its Further Recruitment to the Insulin-Like Growth Factor I Receptor. Mol. Endocrinol., Vol.17, No.9, pp. 1824-33

Loebel, D. a. F.; Watson, C. M.; De Young, A. \& Tam, P. P. L. (2003). Lineage Choice and Differentiation in Mouse Embryos and Embryonic Stem Cells. Dev. Biol., Vol.264, No.1, pp. 1-14

Maheshwari, G.; Brown, G.; Lauffenburger, D. A.; Wells, A. \& Griffith, L. G. (2000). Cell Adhesion and Motility Depend on Nanoscale Rgd Clustering. J. Cell Sci., Vol.113, No.10, pp. 1677-1686

Mao, Y. \& Schwarzbauer, J. E. (2005). Fibronectin Fibrillogenesis, a Cell-Mediated Matrix Assembly Process. Matrix Biol., Vol.24, No.6, pp. 389-399

Mardon, H. J. \& Grant, K. E. (1994). The Role of the 9th and 10th Type-Iii Domains of Human Fibronectin in Cell-Adhesion. FEBS Lett., Vol.340, No.3, pp. 197-201

Martino, M. M.; Mochizuki, M.; Rothenfluh, D. A.; Rempel, S. A.; Hubbell, J. A. \& Barker, T. H. (2009). Controlling Integrin Specificity and Stem Cell Differentiation in 2d and 3d Environments through Regulation of Fibronectin Domain Stability. Biomaterials, Vol.30, No.6, pp. 1089-1097

Memmo, L. M. \& Mckeown-Longo, P. (1998). The Alpha V Beta 5 Integrin Functions as an Endocytic Receptor for Vitronectin. J. Cell Sci., Vol.111, pp. 425-433

Meng, Y.; Eshghi, S.; Li, Y. J.; Schmidt, R.; Schaffer, D. V. \& Healy, K. E. (2009). Characterization of Integrin Engagement During Defined Human Embryonic Stem Cell Culture. FASEB J., Vol.24, No.4, pp. 1056-65

Nishida, N.; Xie, C.; Shimaoka, M.; Cheng, Y.; Walz, T. \& Springer, T. A. (2006). Activation of Leukocyte Beta2 Integrins by Conversion from Bent to Extended Conformations. Immunity, Vol.25, No.4, pp. 583-94

Nishiuchi, R.; Takagi, J.; Hayashi, M.; Ido, H.; Yagi, Y.; Sanzen, N.; Tsuji, T.; Yamada, M. \& Sekiguchi, K. (2006). Ligand-Binding Specificities of Laminin-Binding Integrins: A Comprehensive Survey of Laminin-Integrin Interactions Using Recombinant Alpha 3 Beta 1, Alpha 6 Beta 1, Alpha 7 Beta 1 and Alpha 6 Beta 4 Integrins. Matrix Biol., Vol.25, No.3, pp. 189-197

Norde, W.; Macritchie, F.; Nowicka, G. \& Lyklema, J. (1986). Protein Adsorption at Solid Liquid Interfaces - Reversibility and Conformation Aspects. J. Colloid Interface Sci., Vol.112, No.2, pp. 447-456

Odorico, J. S.; Kaufman, D. S. \& Thomson, J. A. (2001). Multilineage Differentiation from Human Embryonic Stem Cell Lines. Stem Cells, Vol.19, No.3, pp. 193-204 
Ohashi, T.; Kiehart, D. P. \& Erickson, H. P. (1999). Dynamics and Elasticity of the Fibronectin Matrix in Living Cell Culture Visualized by Fibronectin-Green Fluorescent Protein. Proc. Natl. Acad. Sci. U. S. A., Vol.96, No.5, pp. 2153-8

Ohmuro-Matsuyama, Y. \& Tatsu, Y. (2008). Photocontrolled Cell Adhesion on a Surface Functionalized with a Caged Arginine-Glycine-Aspartate Peptide. Angew. Chem.Int. Edit., Vol.47, No.39, pp. 7527-7529

Pankov, R. \& Yamada, K. M. (2002). Fibronectin at a Glance. J. Cell Sci., Vol.115, No.20, pp. 3861-3863

Pelham, R. J., Jr. \& Wang, Y. (1997). Cell Locomotion and Focal Adhesions Are Regulated by Substrate Flexibility. Proc. Natl. Acad. Sci. U. S. A., Vol.94, No.25, pp. 13661-5

Pereira, P.; Kelly, S. M.; Gellert, P. R. \& Van Der Walle, C. F. (2008). Interdomain Mobility and Conformational Stability of Type Iii Fibronectin Domain Pairs Control Surface Adsorption, Desorption and Unfolding. Colloid Surf. B-Biointerfaces, Vol.64, No.1, pp. 1-9

Petersen, S.; Alonso, J. M.; Specht, A.; Duodu, P.; Goeldner, M. \& Del Campo, A. (2008). Phototriggering of Cell Adhesion by Caged Cyclic Rgd Peptides. Angew. Chem.-Int. Edit., Vol.47, No.17, pp. 3192-3195

Petrie, T. A.; Raynor, J. E.; Reyes, C. D.; Burns, K. L.; Collard, D. M. \& Garcia, A. J. (2008). The Effect of Integrin-Specific Bioactive Coatings on Tissue Healing and Implant Osseointegration. Biomaterials, Vol.29, No.19, pp. 2849-57

Pierschbacher, M. D. \& Ruoslahti, E. (1984). Cell Attachment Activity of Fibronectin Can Be Duplicated by Small Synthetic Fragments of the Molecule. Nature, Vol.309, No.5963, pp. 30-3

Plow, E. F.; Haas, T. A.; Zhang, L.; Loftus, J. \& Smith, J. W. (2000). Ligand Binding to Integrins. J Biol Chem, Vol.275, No.29, pp. 21785-8

Randlett, O.; Poggi, L.; Zolessi, F. R. \& Harris, W. A. (2011). The Oriented Emergence of Axons from Retinal Ganglion Cells Is Directed by Laminin Contact in Vivo. Neuron, Vol.70, No.2, pp. 266-80

Rexeisen, E. L.; Fan, W.; Pangburn, T. O.; Taribagil, R. R.; Bates, F. S.; Lodge, T. P.; Tsapatsis, M. \& Kokkoli, E. (2010). Self-Assembly of Fibronectin Mimetic Peptide-Amphiphile Nanofibers. Langmuir, Vol.26, No.3, pp. 1953-9

Robertson, E. J. (Ed.). (1987). Teratocarcinomas and Embryonic Stem Cells: A Practical Approach., Oxford University Press, ISBN 978-1852210052, Oxford, UK

Roy, D. C.; Wilke-Mounts, S. J. \& Hocking, D. C. (2011). Chimeric Fibronectin Matrix Mimetic as a Functional Growth- and Migration-Promoting Adhesive Substrate. Biomaterials, Vol.32, No.8, pp. 2077-87

Salinas, C. N. \& Anseth, K. S. (2008). The Enhancement of Chondrogenic Differentiation of Human Mesenchymal Stem Cells by Enzymatically Regulated Rgd Functionalities. Biomaterials, Vol.29, No.15, pp. 2370-2377

Samanen, J.; Jonak, Z.; Rieman, D. \& Yue, T. L. (1997). Vascular Indications for Integrin Alpha V Antagonists. Curr. Pharm. Design, Vol.3, No.6, pp. 545584 
Shattil, S. J. (1999). Signaling through Platelet Integrin Alpha Iib Beta 3: Inside-out, Outsidein, and Sideways. Thromb. Haemost., Vol.82, No.2, pp. 318-25

Shin, H. (2007). Fabrication Methods of an Engineered Microenvironment for Analysis of Cell-Biomaterial Interactions. Biomaterials, Vol.28, No.2, pp. 126-33

Shin, T. M.; Isas, J. M.; Hsieh, C. L.; Kayed, R.; Glabe, C. G.; Langen, R. \& Chen, J. (2008). Formation of Soluble Amyloid Oligomers and Amyloid Fibrils by the Multifunctional Protein Vitronectin. Mol. Neurodegener., Vol.3pp. 16

Singh, M. D.; Kreiner, M.; Mckimmie, C. S.; Holt, S.; Van Der Walle, C. F. \& Graham, G. J. (2009). Dimeric Integrin Alpha5beta1 Ligands Confer Morphological and Differentiation Responses to Murine Embryonic Stem Cells. Biochem. Biophys. Res. Commun., Vol.390, No.3, pp. 716-21

Stockmann, A.; Hess, S.; Declerck, P.; Timpl, R. \& Preissner, K. T. (1993). Multimeric Vitronectin. Identification and Characterization of Conformation-Dependent SelfAssociation of the Adhesive Protein. J. Biol. Chem., Vol.268, No.30, pp. 22874-82

Su, T. J.; Lu, J. R.; Thomas, R. K.; Cui, Z. F. \& Penfold, J. (1998). The Adsorption of Lysozyme at the Silica-Water Interface: A Neutron Reflection Study. J. Colloid Interface Sci., Vol.203, No.2, pp. 419-429

Takagi, J.; Petre, B. M.; Walz, T. \& Springer, T. A. (2002). Global Conformational Rearrangements in Integrin Extracellular Domains in Outside-in and inside-out Signaling. Cell, Vol.110, No.5, pp. 599-11

Takagi, J.; Strokovich, K.; Springer, T. A. \& Walz, T. (2003). Structure of Integrin Alpha5beta1 in Complex with Fibronectin. EMBO J., Vol.22, No.18, pp. 4607-15

Tapley, P.; Horwitz, A.; Buck, C.; Duggan, K. \& Rohrschneider, L. (1989). Integrins Isolated from Rous Sarcoma Virus-Transformed Chicken Embryo Fibroblasts. Oncogene, Vol.4, No.3, pp. 325-33

Thomas, G. J.; Nystrom, M. L. \& Marshall, J. F. (2006). Alphavbeta6 Integrin in Wound Healing and Cancer of the Oral Cavity. J. Oral Pathol. Med., Vol.35, No.1, pp. $1-10$

Thomson, J. A.; Itskovitz-Eldor, J.; Shapiro, S. S.; Waknitz, M. A.; Swiergiel, J. J.; Marshall, V. S. \& Jones, J. M. (1998). Embryonic Stem Cell Lines Derived from Human Blastocysts. Science, Vol.282, No.5391, pp. 1145-1147

Van Der Walle, C. F.; Altroff, H. \& Mardon, H. J. (2002). Novel Mutant Human Fibronectin Fiii9-10 Domain Pair with Increased Conformational Stability and Biological Activity. Protein Engineering, Vol.15, No.12, pp. 1021-1024

Von Wichert, G.; Haimovich, B.; Feng, G. S. \& Sheetz, M. P. (2003). Force-Dependent Integrin-Cytoskeleton Linkage Formation Requires Downregulation of Focal Complex Dynamics by Shp2. EMBO J., Vol.22, No.19, pp. 5023-35

Watson, N.; Duncan, G.; Annan, W. S. \& Van Der Walle, C. F. (2006). A Tetravalent Rgd Ligand for Integrin-Mediated Cell Adhesion. J. Pharm. Pharmacol., Vol.58, No.7, pp. 959-66

Wayner, E. A.; Orlando, R. A. \& Cheresh, D. A. (1991). Integrin-Alpha-V-Beta-3 and Integrin-Alpha-V-Beta-5 Contribute to Cell Attachment to Vitronectin but 
Differentially Distribute on the Cell-Surface. J. Cell Biol., Vol.113, No.4, pp. 919-929

Wertz, C. F. \& Santore, M. M. (1999). Adsorption and Relaxation Kinetics of Albumin and Fibrinogen on Hydrophobic Surfaces: Single-Species and Competitive Behavior. Langmuir, Vol.15, No.26, pp. 8884-8894

Wertz, C. F. \& Santore, M. M. (2002). Adsorption and Reorientation Kinetics of Lysozyme on Hydrophobic Surfaces. Langmuir, Vol.18, No.4, pp. 1190-1199

Wess, T. J. (2005). Collagen Fibril Form and Function. In: Fibrous Proteins: Coiled-Coils, Collagen and Elastomers, Parry, D. A. D. \& Squire, J. M. (Eds.), 342-374, Elsevier Inc., ISBN 012034270 7, California, USA

White, E. S.; Baralle, F. E. \& Muro, A. F. (2008). New Insights into Form and Function of Fibronectin Splice Variants. J. Pathol., Vol.216, No.1, pp. 1-14

Wood, L. L.; Cheng, S. S.; Edmiston, P. L. \& Saavedra, S. S. (1997). Molecular Orientation Distributions in Protein Films.2. Site- Directed Immobilization of Yeast Cytochrome C on Thiol-Capped, Self-Assembled Monolayers. J. Am. Chem. Soc., Vol.119, No.3, pp. $571-576$

Wozniak, M. A.; Modzelewska, K.; Kwong, L. \& Keely, P. J. (2004). Focal Adhesion Regulation of Cell Behavior. Biochim. Biophys. Acta, Vol.1692, No.2-3, pp. 103-19

Xiong, J. P.; Stehle, T.; Diefenbach, B.; Zhang, R.; Dunker, R.; Scott, D. L.; Joachimiak, A.; Goodman, S. L. \& Arnaout, M. A. (2001). Crystal Structure of the Extracellular Segment of Integrin Alpha Vbeta3. Science, Vol.294, No.5541, pp. $339-45$

Xiong, J. P.; Stehle, T.; Zhang, R.; Joachimiak, A.; Frech, M.; Goodman, S. L. \& Arnaout, M. A. (2002). Crystal Structure of the Extracellular Segment of Integrin Alpha Vbeta3 in Complex with an Arg-Gly-Asp Ligand. Science, Vol.296, No.5565, pp. 151-5

Yamada, Y.; Katagiri, F.; Hozumi, K.; Kikkawa, Y. \& Nomizu, M. (2011). Cell Behavior on Protein Matrices Containing Laminin Alpha1 Peptide AG73. Biomaterials, Vol.32, No.19, pp. 4327-35

Yamashita, Y. M.; Fuller, M. T. \& Jones, D. L. (2005). Signaling in Stem Cell Niches: Lessons from the Drosophila Germline. J. Cell Sci., Vol.118, No.4, pp. 665672

Yauch, R. L.; Felsenfeld, D. P.; Kraeft, S. K.; Chen, L. B.; Sheetz, M. P. \& Hemler, M. E. (1997). Mutational Evidence for Control of Cell Adhesion through Integrin Diffusion/Clustering, Independent of Ligand Binding. J. Exp. Med., Vol.186, No.8, pp. 1347-55

Young, J. L. \& Engler, A. J. (2011). Hydrogels with Time-Dependent Material Properties Enhance Cardiomyocyte Differentiation in Vitro. Biomaterials, Vol.32, No.4, pp. 1002-9

Zhang, S. G.; Marini, D. M.; Hwang, W. \& Santoso, S. (2002). Design of Nanostructured Biological Materials through Self-Assembly of Peptides and Proteins. Curr. Opin. Chem. Biol., Vol.6, No.6, pp. 865-871 
Zhou, M.; Smith, A. M.; Das, A. K.; Hodson, N. W.; Collins, R. F.; Ulijn, R. V. \& Gough, J. E. (2009). Self-Assembled Peptide-Based Hydrogels as Scaffolds for AnchorageDependent Cells. Biomaterials, Vol.30, No.13, pp. 2523-30

Zhu, J.; Luo, B. H.; Xiao, T.; Zhang, C.; Nishida, N. \& Springer, T. A. (2008). Structure of a Complete Integrin Ectodomain in a Physiologic Resting State and Activation and Deactivation by Applied Forces. Mol. Cell, Vol.32, No.6, pp. 849-61 


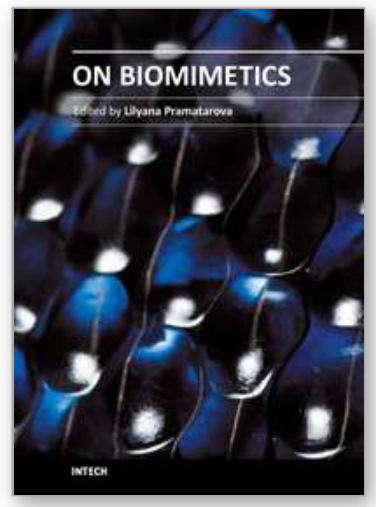

\author{
On Biomimetics \\ Edited by Dr. Lilyana Pramatarova
}

ISBN 978-953-307-271-5

Hard cover, 642 pages

Publisher InTech

Published online 29, August, 2011

Published in print edition August, 2011

Bio-mimicry is fundamental idea â€ How to mimic the Natureâ€TM by various methodologies as well as new ideas or suggestions on the creation of novel materials and functions. This book comprises seven sections on various perspectives of bio-mimicry in our life; Section 1 gives an overview of modeling of biomimetic materials; Section 2 presents a processing and design of biomaterials; Section 3 presents various aspects of design and application of biomimetic polymers and composites are discussed; Section 4 presents a general characterization of biomaterials; Section 5 proposes new examples for biomimetic systems; Section 6 summarizes chapters, concerning cells behavior through mimicry; Section 7 presents various applications of biomimetic materials are presented. Aimed at physicists, chemists and biologists interested in biomineralization, biochemistry, kinetics, solution chemistry. This book is also relevant to engineers and doctors interested in research and construction of biomimetic systems.

\title{
How to reference
}

In order to correctly reference this scholarly work, feel free to copy and paste the following:

Lisa McIntosh and Christopher F. van der Walle (2011). Control of Mammalian Cell Behaviour Through Mimicry of the Extracellular Matrix Environment, On Biomimetics, Dr. Lilyana Pramatarova (Ed.), ISBN: 978953-307-271-5, InTech, Available from: http://www.intechopen.com/books/on-biomimetics/control-ofmammalian-cell-behaviour-through-mimicry-of-the-extracellular-matrix-environment

\section{INTECH}

open science | open minds

\section{InTech Europe}

University Campus STeP Ri

Slavka Krautzeka 83/A

51000 Rijeka, Croatia

Phone: +385 (51) 770447

Fax: +385 (51) 686166

www.intechopen.com

\section{InTech China}

Unit 405, Office Block, Hotel Equatorial Shanghai No.65, Yan An Road (West), Shanghai, 200040, China 中国上海市延安西路65号上海国际贵都大饭店办公楼405单元 Phone: +86-21-62489820

Fax: $+86-21-62489821$ 
(C) 2011 The Author(s). Licensee IntechOpen. This chapter is distributed under the terms of the Creative Commons Attribution-NonCommercialShareAlike-3.0 License, which permits use, distribution and reproduction for non-commercial purposes, provided the original is properly cited and derivative works building on this content are distributed under the same license. 